\title{
Erratum to: Expression of mung bean pectin acetyl esterase in potato tubers: effect on acetylation of cell wall polymers and tuber mechanical properties
}

\author{
Caroline Orfila $\cdot$ Florence Dal Degan . \\ Bodil Jørgensen · Henrik Vibe Scheller • \\ Peter M. Ray $\cdot$ Peter Ulvskov
}

Published online: 7 April 2012

(C) Springer-Verlag 2012

\section{Erratum to: Planta}

DOI 10.1007/s00425-012-1596-z

In the online publication, the plotting symbols were inadvertently omitted in Fig. 7. The author regrets this omission and the correct version is given below.

The online version of the original article can be found under doi:10.1007/s00425-012-1596-z.

C. Orfila · F. D. Degan · B. Jørgensen · H. V. Scheller •

P. Ulvskov $(\bowtie)$

Department of Plant Biology and Biotechnology,

University of Copenhagen, Thorvaldsensvej 40,

1871 Frederiksberg C, Denmark

e-mail: ulvskov@life.ku.dk

Present Address:

C. Orfila

School of Food Science and Nutrition,

University of Leeds, Leeds LS2 9JT, UK

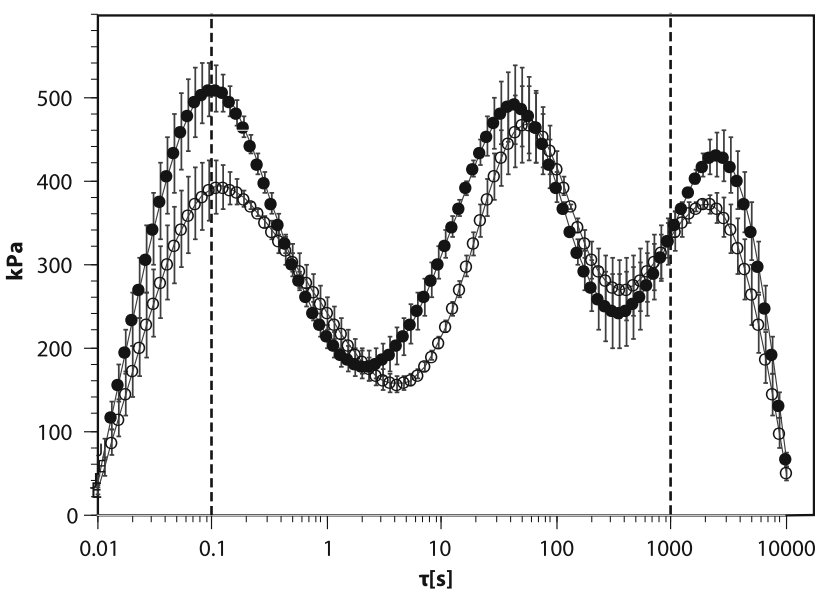

Fig. 7 Relaxation spectra of wild type (open symbols) and PAT31 (closed symbols). Dashed lines indicate the reliable range; meaning of error bars is given in Hansen et al. (2011). $\tau$ time in $\mathrm{s}$

\section{H. V. Scheller}

Feedstocks Division, Joint BioEnergy Institute,

Lawrence Berkeley National Laboratory, Emeryville, CA 94608, USA

H. V. Scheller

Department of Plant and Microbial Biology,

University of California, Berkeley, CA 94720, USA

\section{P. M. Ray}

Department of Biological Sciences, Stanford University, Serra Street, Stanford, CA 94305, USA

Present Address:

F. D. Degan

ZEALAND Pharma A/S, Smedeland 36,

2600 Glostrup, Denmark

Present Address:

B. Jørgensen

Department of Agriculture and Ecology, Copenhagen University,

Thorvaldsensvej 40, 1871 Frederiksberg C, Denmark 